17) 無機応用比色分析委員会編, 「無機応用比色分析」 2 (Cl$\mathrm{Ge}$ ), 共立出版, p. 158-246 (1974).

18) R. Hakim, D. Uhlmann, Phys. Chem. Glasses, 12 [5] 132-38 (1971); 岸井 貫, 「ガラスハンドブック」 （作花済夫，境野照雄，高橋克明編） p. 590, 朝倉 書店 (1975).

19）永野正光，加藤昭夫，持田 勲,清山哲郎, 㷱協, 78 [12] 401-10 (1970).

20) W.D. Johnston, J. Amer. Ceram. Soc., 48 [4] 18490 (1965).

21) P. Nath, R.W. Douglas, Phys. Chem. Glasses, 6 [6] 197-202 (1965).

22) R.W. Douglas, P. Nath and A. Paul, Phys. Chem. Glasses, 6 [6] 216-23 (1965).

23) A.P. Herring, Phys. Chem. Glasses, 7 [6] 209-10 (1966).

24) S.M. Budd, Phys. Chem. Glasses, 7 [6] 210-13 (19
$66)$.

25) S.B. Holmquist, J. Amer. Ceram. Soc., 49 [4] 22829 (1966).

26) T. Yokokawa, S. Tamura, S. Saito, K. Niwa, Phys. Chem. Glasses, 15 [5] 113-15 (1974).

27) R. Majumdar, D. Lahiri, J. Amer. Ceram. Soc., 85 [3-4] 99-101 (1975).

28) A. Paul, D. Lahiri, J. Amer. Ceram. Soc., 49 [10] 565-68 (1966).

29）平島 碩, 豊田洋一, 吉田哲郎, 窯協, 82 [6] 309-16 (1974).

30）吉田哲郎, 岡田有次, 平島 碩, 窯協, 81 [7] 281-89 (1973).

31）吉田哲郎, 新井一正, 橋本忠浩, 岡田有次, 蓔協, 81 [4] 139-48 (1973).

(3/11/1975 受付)

実験・技術・調査報告 $\cdot$ Report

\title{
含チタン燐酸塩ガラスの電気伝導
}

\author{
林卓・本多康二・斎藤肇 \\ (名古屋大学 工学部 応用化学科)
}

\section{Electrical Resistivity of Phosphate Glasses containing Titanium}

\author{
By \\ Takashi HAYASHI, Kouji HONDA and Hajime SAITO \\ (Department of Applied Chemistry, Faculty of Engineering, Nagoya University)
}

The compositional range of the glass formation in the system $\mathrm{RO}\left(\mathrm{R}_{2} \mathrm{O}\right)-\mathrm{TiO}_{2}-\mathrm{P}_{2} \mathrm{O}_{5}(\mathrm{R}=$ $\mathrm{K}, \mathrm{Ca}, \mathrm{Be}$ ) and electrical resistivity of the glasses were studied.

The results are summarized as follows;

1) The compositional range of the glass formation obtained by the quenching method was similar to each other in three systems $(\mathrm{R}=\mathrm{K}, \mathrm{Ca}, \mathrm{Be})$.

In glasses, maximum contents of $\mathrm{TiO}_{2}$ were $65 \mathrm{~mol} \%$.

2) In the $10 \mathrm{~K}_{2} \mathrm{O} \cdot 50 \mathrm{TiO}_{2} \cdot 40 \mathrm{P}_{2} \mathrm{O}_{5}$ composition glass, the precipitated crystal by heat treatment at $800^{\circ} \mathrm{C}$ were $\mathrm{TiO}_{2}$ (anatase) and unknown crystal $\left(\mathrm{K}_{2} \mathrm{O} \cdot \mathrm{TiO}_{2} \cdot \mathrm{P}_{2} \mathrm{O}_{5}\right.$ system).

3) The temperature dependence of resistivity for the phosphate glasses containing $\mathrm{Ti}^{3+}$ was given by

$$
\rho=\rho_{0} \exp (\Delta E / k T)
$$

in which $\rho$ is resistivity, $\rho_{0}$, constant, $\Delta E$, activation energy, $T$, absolute temperature, and $k$, Boltzman's constant. But the linear relationship between $\log \rho$ and $1 / T$ bent into two straight line in all glasses in the neighborhood of $100^{\circ} \mathrm{C}$. In the $x \mathrm{~K}_{2} \mathrm{O}-(60-x)$ $\mathrm{TiO}_{2}-40 \mathrm{P}_{2} \mathrm{O}_{5}$ system, the resistivity of the glasses decreased with increasing $\mathrm{TiO}_{2}$ contents. Addition of $\mathrm{Ti}^{3+}$ ion to the base glass $\left(10 \mathrm{~K}_{2} \mathrm{O} \cdot 50 \mathrm{TiO}_{2} \cdot 40 \mathrm{P}_{2} \mathrm{O}_{5}\right)$ decreased electrical resistivity very much, and also decreased the apparent activation energies for electrical conduction.

4) The electrical resistivity of crystallized glasses decreased with increasing the quantity of crystal deposited in the glasses and the concentration of $\mathrm{Ti}^{3+}$ ion. It was assumed that the decreases of resistivity by crystallization were due to the deposition of nonstoichiometric crystals having higher electrical conductivities. 
5) The Seebeck coefficient was nearly independent on temperature in the range of 40 to $150^{\circ} \mathrm{C}$ and it's values were $-0.36 \mathrm{mV} /{ }^{\circ} \mathrm{C}$.

6) By addition of a small amounts of $\mathrm{FeO}$ or $\mathrm{V}_{2} \mathrm{O}_{3}$ to base glass, electrical resistivities were decreased about one order of magnitude.

[Received October 7,1975]

\section{1. 緒言}

バナジウム，モリブデン，タングステンなどの遷移金 属を含む酸化物半導性ガラスは, 多くの研究者によって 報告 ${ }^{12 \sim 3)}$ さており，これらのガラスの伝導度は主に遷 移金属の含有量によって変化するが，その他に熔融条 件, 微量の不純物の存在によって大きな影響を受けると 言われている.これらの遷移元素酸化物を主成分とする ガラスのうち, バナジウムガラスが最も多く研究され， かつ抵抗も小さい.これに対し，チタンを含む酸化物半 導性ガラスについてはあまり報告4),5)されていない. またガラス中の $\mathrm{Ti}^{3+}$ は還元剤の添加または還元雾囲気 によって生成されているため, 熔融条件（時間, 温度） によって著しく影響を受けやすい.

そこで本研究では，酸化チタンを含むガラスのガラス 化範囲を求め, さらにえられたガラスに $\mathrm{Ti}_{2} \mathrm{O}_{3}$ を添加 したガラス試料および結晶化試料の電気伝導性について 検討した.

\section{2. 実 験}

\section{1 ガラスの調製}

ガラスの原料として市販特級の $\mathrm{K}_{2} \mathrm{CO}_{3}, \mathrm{CaCO}_{3}, \mathrm{TiO}_{2}$, $\mathrm{BeO}, \mathrm{H}_{3} \mathrm{PO}_{4}$ (85\%) を用いた. 原料を所定の組成にな るように白金皿に入れ，少量の水を加えて均一に混合 し，200 300 $\mathrm{C}$ でゆっくり加熱して完全に固化した. その後, 固化物を粉砕し, 白金チューブに入れ， $850^{\circ} \mathrm{C}$ で脱水, 脱炭酸を行ったのち密封し, $1400^{\circ} \mathrm{C}$ で 1 時間 保って熔融した. 熔融後, 水中で急冷し, その試料を肉 眼および偏光顕微鏡でガラス化の有無を調べた．導電性

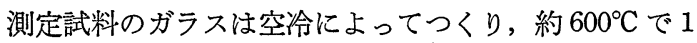
時間保持したのち, $10^{\circ} \mathrm{C} / \mathrm{min}$ で徐冷した. 用いたガラ スは, $\mathrm{K}_{2} \mathrm{O}-\mathrm{TiO}_{2}-\mathrm{P}_{2} \mathrm{O}_{5}$ 系, $\mathrm{CaO}-\mathrm{TiO}_{2}-\mathrm{P}_{2} \mathrm{O}_{5}$ 系および $\mathrm{BeO}-\mathrm{TiO}_{2}-\mathrm{P}_{2} \mathrm{O}_{5}$ 系より選んだが， $\mathrm{TiO}_{2}$ を多量に含む 組成では，いずれもかなり失透した。

また $\mathrm{K}_{2} \mathrm{O}-\mathrm{TiO}_{2}-\mathrm{P}_{2} \mathrm{O}_{5}$ 系に対しては，基礎ガラスとし て $10 \mathrm{~K}_{2} \mathrm{O}-50 \mathrm{TiO}_{2}-40 \mathrm{P}_{2} \mathrm{O}_{5}$ を選び，この組成のガラス を調製し，粉砕したのち， $\mathrm{Ti}_{2} \mathrm{O}_{3}$ を 0 10 モル \% 添加 した.このガラスの調製は, 空気による $\mathrm{Ti}^{3+}$ の酸化を 防ぐために密封した白金チューブで行った.

$\mathrm{Ti}_{2} \mathrm{O}_{3}$ の合成は, $\mathrm{Ti}+3 \mathrm{TiO}_{2} \rightarrow 2 \mathrm{Ti}_{2} \mathrm{O}_{3}$ の反応に従 、行った. すなわち, 金属チタンと酸化チタンをモル比 $1: 3$ の割合で混合し, 約 1 ton の加圧下でペレットに 成形して, Ar 気流中で $1400^{\circ} \mathrm{C}, 8$ 時間反応させた.
Table 1. Compositions of titanium phosphate glasses composition ( $\mathrm{mol} \%$ ).

\begin{tabular}{rrrrrrrr}
\hline $\begin{array}{c}\text { Glass } \\
\text { No. }\end{array}$ & $\mathrm{P}_{2} \mathrm{O}_{5}$ & $\mathrm{~K}_{2} \mathrm{O}$ & $\mathrm{CaO}$ & $\mathrm{BeO}$ & $\mathrm{TiO}_{2}$ & $\overbrace{\text { calcd. }}^{\mathrm{Ti}_{2} \mathrm{O}_{3}}$ & found \\
\hline 1 & 40 & & & & 60 & & \\
2 & 40 & 10 & & & 50 & & \\
3 & 40 & 20 & & & 40 & & \\
4 & 40 & 30 & & & 30 & & \\
5 & 40 & & 10 & & 50 & & \\
6 & 40 & & 30 & & 30 & & \\
7 & 60 & & 40 & & 0 & & \\
8 & 40 & & & 10 & 50 & & \\
9 & 40 & 10 & & & 50 & 0.5 & 0.8 \\
10 & 40 & 10 & & & 50 & 1.0 & 1.1 \\
11 & 40 & 10 & & & 50 & 3.0 & 2.7 \\
12 & 40 & 10 & & & 50 & 5.0 & 4.4 \\
13 & 40 & 10 & & & 50 & 10.0 & 8.9 \\
14 & 40 & 10 & & & 49 & 1.0 & 1.2 \\
15 & 40 & 10 & & & 48.5 & 1.5 & 1.8 \\
16 & 40 & 10 & & & 48 & 2.0 & 2.0 \\
17 & 40 & 10 & & & 45 & 5.0 & 4.6 \\
\hline
\end{tabular}

この生成物は，X線回折の結果， $\mathrm{Ti}_{2} \mathrm{O}_{3}$ と同定され， 未反応の $\mathrm{TiO}_{2}$ のピークは認められなかった. また化学 分析からこの生成物の組成式は $\mathrm{TiO}_{1.6}$ で示された.

測定に用いたガラス番号と組成を表 1 に示した.ガラ ス中の $\mathrm{Ti}^{3+}$ の分析值も併せて示した.

\section{2 電気抵抗の測定}

測定試料の両面に $\mathrm{Pt}-\mathrm{Pd}$ 合金または銀を蒸着し，ガ ードリングを付けた電極を使用して, 振動容量型直流増 幅器（タケダ理研 TR 8651）を用いて測定した.

\section{3 熱処理}

試料ガラスを白金チューブ中に入れ，密封後，示差熱 分析の発熱ピーク温度で加熱処理し, 結晶化させた.

\section{4 試料中の $\mathrm{Ti}^{3+}$ の化学分析}

試料約 $0.3 \mathrm{~g}$ を精秤し, 白金血にとり, $\mathrm{N} / 30 \mathrm{NH}_{4} \mathrm{VO}_{3}$ $10 \mathrm{cc}$ と (1:3) $\mathrm{H}_{2} \mathrm{SO}_{4} 30 \mathrm{cc}$ を加え, 弱火で加熱し, 液があたたまってから $46 \% \mathrm{HF} 10 \mathrm{cc}$ を加えて分解す る. 一定量に稀釈した分解液をジフェニルアミン指示薬 を用いて， $\mathrm{N} / 30 \mathrm{FeSO}_{4}$ で滴定する.

\section{3. 実験結果および考察}

\section{1 ガラス化範囲}

$\mathrm{K}_{2} \mathrm{O}-\mathrm{TiO}_{2}-\mathrm{P}_{2} \mathrm{O}_{5}$ 系, $\mathrm{CaO}-\mathrm{TiO}_{2}-\mathrm{P}_{2} \mathrm{O}_{5}$ 系および $\mathrm{BeO}-$ $\mathrm{TiO}_{2}-\mathrm{P}_{2} \mathrm{O}_{5}$ 系のガラス化範囲を図 1 に示した. 3 つの系 のガラス化範囲は，ほぼ類似しており，いずれも NWM の低濃度のところでガラス化範囲が広く, $\mathrm{TiO}_{2}$ 量を多 

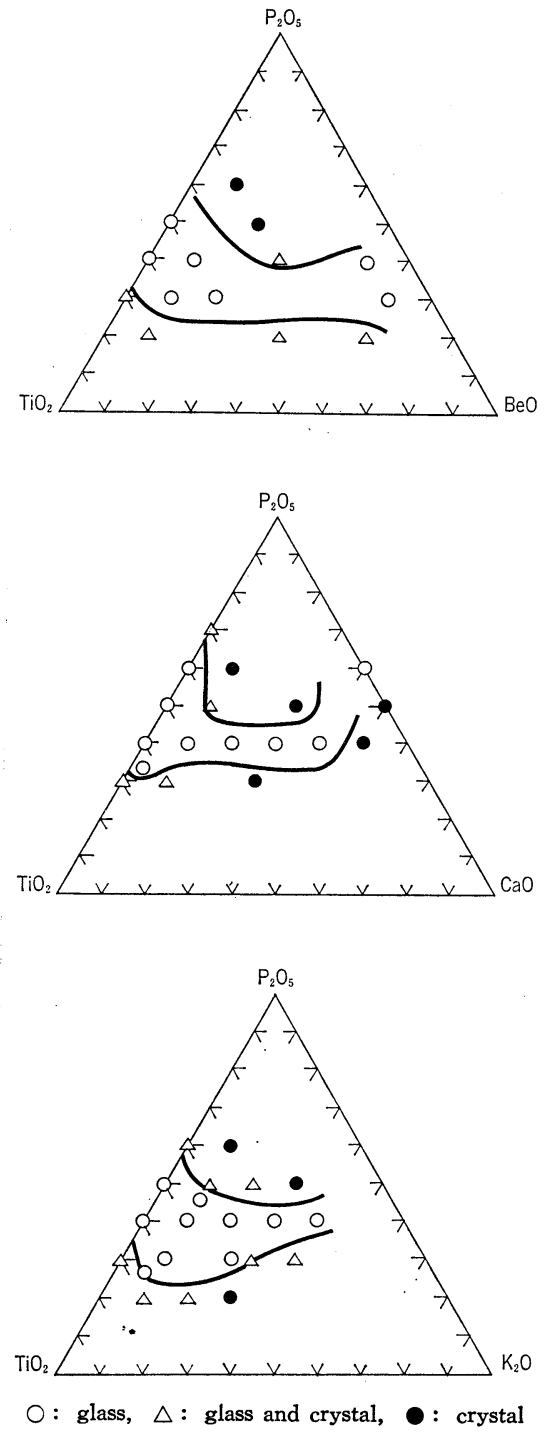

Fig. 1. Glass-forming regions in the system RO $\left(\mathrm{R}_{2} \mathrm{O}\right)-\mathrm{TiO}_{2}-\mathrm{P}_{2} \mathrm{O}_{5}(\mathrm{R}=\mathrm{K}, \mathrm{Ca}, \mathrm{Be})$.

く含んでいるが,これは $\mathrm{TiO}_{2}$ が $\mathrm{NWM}$ としてだけで なく NWF として作用しているためと考えられる.ガ ラス中の $\mathrm{TiO}_{2}$ の最大濃度は約 65 モル $\%$ であり，それ 以上では失透化した．またガラス化しなかった試料の $\mathrm{X}$ 線回折を行った結果, 主結晶として $\mathrm{CaO}$ 系では $\mathrm{TiP}_{2} \mathrm{O}_{7}$, $\mathrm{Ca}_{2} \mathrm{P}_{2} \mathrm{O}_{7}$ および $\mathrm{CaTi}\left(\mathrm{PO}_{4}\right)_{2}, \mathrm{~K}_{2} \mathrm{O}$ 系では $2 \theta=24.2$, 31.6, 21.2，29.1 にピークを持つ同定できない未知結 晶, $\mathrm{BeO}$ 系では $\mathrm{TiO}_{2}$ (anatase), $\mathrm{Be}_{2} \mathrm{P}_{2} \mathrm{O}_{7}$ および $2 \theta=$ 22, 6, 27.8, 38.0 にピークを持つ同定できない未知結晶 などが認められた。

\section{2 ガラスの結晶化}

$\mathrm{K}_{2} \mathrm{O}-\mathrm{TiO}_{2}-\mathrm{P}_{2} \mathrm{O}_{5}$ 系のガラスに対してのみ DTA の発
(1)

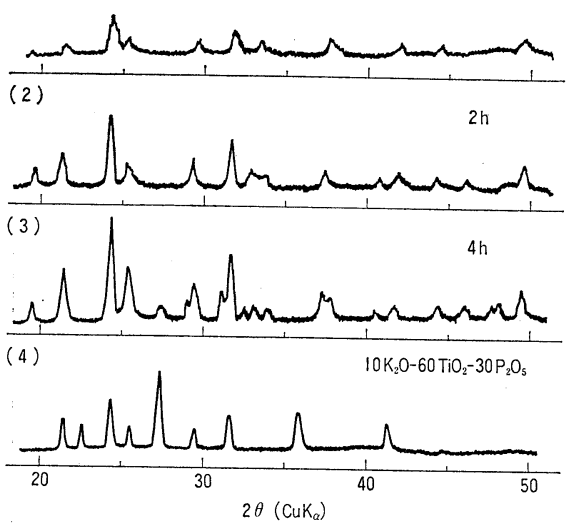

Fig. 2. X-ray diffraction patterns of specimens heated under various conditions (No 12) and sintered material of $\mathrm{Na}_{2} \mathrm{O} \cdot 5 \mathrm{TiO}_{2} \cdot 4 \mathrm{P}_{2} \mathrm{O}_{5}$.

熱ピーク温度 $\left(800^{\circ} \mathrm{C}\right)$ で熱処理を行い，結晶化させた。 $800^{\circ} \mathrm{C}$ で結晶化させた No. 12 試料のX線回折図を図2 に示した. その $\mathrm{X}$ 線回折の結果, 析出結晶は主に $\mathrm{TiO}_{2}$ (anatase) および $2 \theta=24.4,31.7,21.4,29.2$ 付近に回 折ピークを示す同定できない未知結晶であった. 主結晶 である未知結晶の析出量は，熱処理時間の増加とともに 増加する傾向にあった．また未知結晶を調べるため固相 反応を行った結果, $\mathrm{K}_{2} \mathrm{O}, \mathrm{TiO}_{2}, \mathrm{P}_{2} \mathrm{O}_{5}$ の 3 成分からある 一成分を除去した 2 成分系では未知結晶はえられず， 3 成分系では未知結晶に一致するピークが認められること から (図 2(4)), この未知結晶は, $x \mathrm{~K}_{2} \mathrm{O} \cdot y \mathrm{TiO}_{2} \cdot z \mathrm{P}_{2} \mathrm{O}_{5}$ の組成を持つものと推定された.

\section{3 電気抵抗}

$\mathrm{K}_{2} \mathrm{O}-\mathrm{TiO}_{2}-\mathrm{P}_{2} \mathrm{O}_{5}$ 系, $\mathrm{CaO}-\mathrm{TiO}_{2}-\mathrm{P}_{2} \mathrm{O}_{5}$ 系および $\mathrm{BeO}$ $-\mathrm{TiO}_{2}-\mathrm{P}_{2} \mathrm{O}_{5}$ 系ガラス（No 1 No 8) の比抵抗の温度依 存性を図 3, 図 4 に示した. 、ずれのガラスにおいても イオン伝導性ガラスに見られるような著しい分極現象は 認められず, $\log \rho$ と $1 / T$ の間に直線関係があり, 25 $\sim 350^{\circ} \mathrm{C}$ で式 (1) に従った.

$$
\rho=\rho_{0} \exp (\Delta E / k T)
$$

ここで $\rho$ は比抵抗, $\rho_{0}$ は定数, $E$ は活性化エネルギー, $k$ はボルツマン定数, $T$ は絶対温度である.いずれの試料の 比抵抗の温度依存性においても, $100^{\circ} \mathrm{C}$ 前後で明瞭な折 れ曲りを示す. この折れ曲りは, $350^{\circ} \mathrm{C}$ 以上で長時間, 十 分に加熱すると小さくなるが，完全に消失しないことか ら表面に吸着した水分の影響()だけでは説明できない. 一般に遷移金属を含むガラスにおいて $80 \sim 100^{\circ} \mathrm{C}$ 付近に 折れ曲りを示すことは, 多くの研究者 ${ }^{7010)}$ にって報告 されているがまだ明らかにされていない．また $\mathrm{TiO}_{2} の$ 導入量の増加とともに比抵抗が減少し, $\mathrm{TiO}_{2}$ が導電性 に対して支配的因子であると考えられた. 活性化エネル ギーは, 低温側では $0.4 \sim 0.6 \mathrm{eV}$ であり, 高温側では 


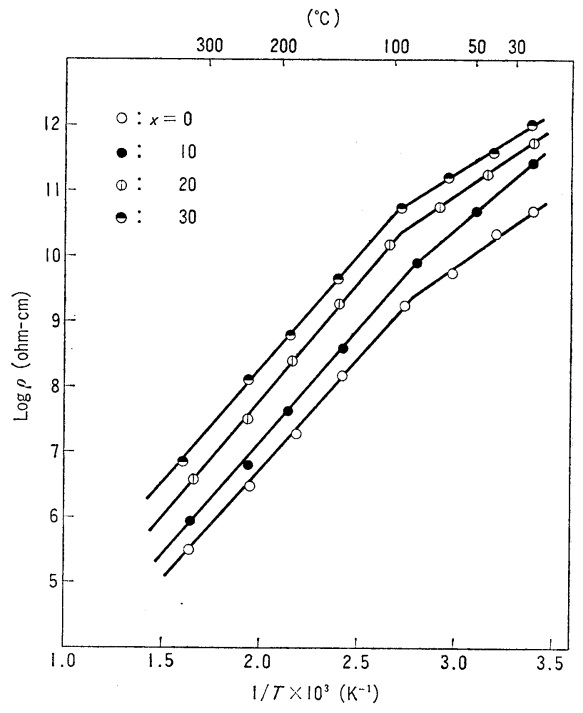

Fig. 3. The temperature dependence of resistivity in glasses of the formula $x \mathrm{~K}_{2} \mathrm{O}-(60-x)$ $\mathrm{TiO}_{2}-40 \mathrm{P}_{2} \mathrm{O}_{5}$.

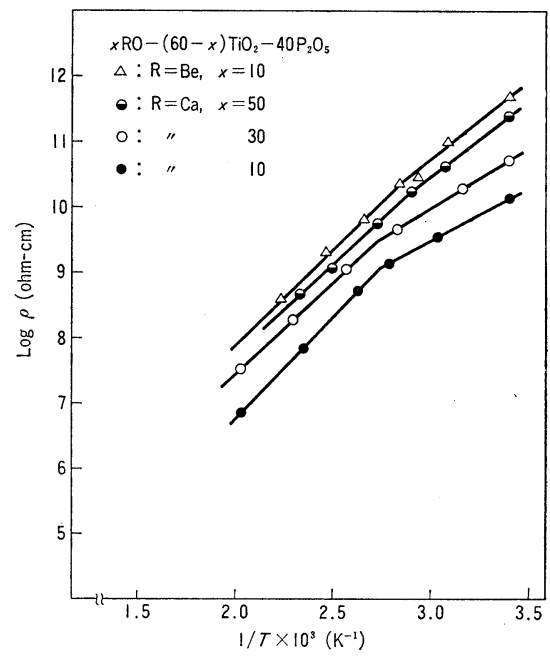

Fig. 4. The temperature dependence of resistivity in glasses of the formula $x \mathrm{RO}-(60-x)$ $\mathrm{TiO}_{2}-40 \mathrm{P}_{2} \mathrm{O}_{5}(\mathrm{R}=\mathrm{Ca}, \mathrm{Be})$.

$0.6 \sim 0.9 \mathrm{eV}$ となり, $\mathrm{TiO}_{2}$ 量の増加と共に減少する傾 向にあった。

つぎに修飾イオン $\left(\mathrm{K}^{+}, \mathrm{Ca}^{2+}, \mathrm{Be}^{2+}\right)$ の cationic field strength (C.F.S.—z/ $z / a^{2} ; z$ : 各イオンの電荷, $a$ : 酸素 イオンとのイオン間距離）と比抵抗の関係を図 5 に示し た. 宗像 ${ }^{11} ら に よ り$ 報告されているように陽イオンの起 分極能*が小さいほど電子授受に対する妨害作用が小さ く抵抗は小さくなると考えられる. C.F.S と比抵抗の間 には上で述べたような単調な比例関係は成り立たなかっ

*酸化物に対して C.F.S. は起分極の一つの尺度である.

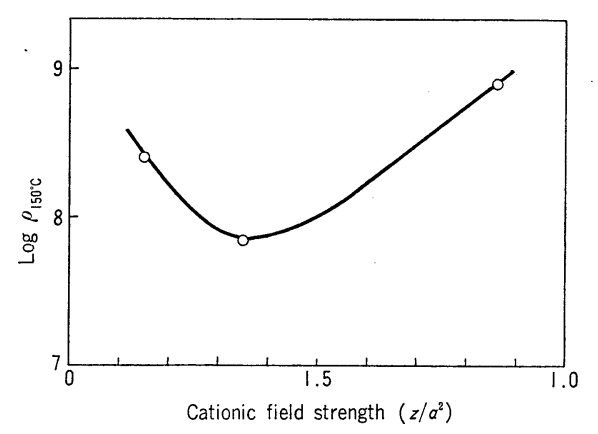

Fig. 5. The relation between resistivity at $150^{\circ} \mathrm{C}$ and cationic field strength of $\mathrm{R}$ ion of the glasses $10 \mathrm{RO}\left(\mathrm{R}_{2} \mathrm{O}\right)-50 \mathrm{TiO}_{2}-40 \mathrm{P}_{2} \mathrm{O}_{5}$.

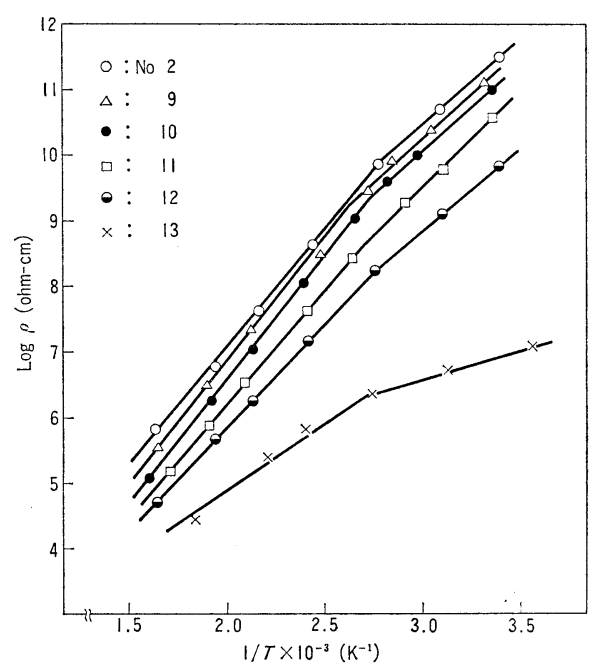

Fig. 6. The temperature dependence of resistivity for the glasses containing $\mathrm{Ti}^{3+}$ (No. $9 \sim$ No. 13).

た. これは比抵抗が各陽イオンの $\mathrm{O}^{2-}$ イオンに対する 静電的引力だけに関係しているのではなく，ガラスの開 放構造にも関係しているためと推察された.

\section{4 比抵抗におよぼす $\mathbf{T i}^{\mathbf{3}+}$ の影響}

基礎ガラス $\left(10 \mathrm{~K}_{2} \mathrm{O}-50 \mathrm{TiO}_{2}-40 \mathrm{P}_{2} \mathrm{O}_{5}\right)$ に $\mathrm{Ti}^{3+}$ を添 加し調製したガラス（No 9 No 13）の比抵抗の温度依 存性を図 6 に示した。基礎ガラスに比べ, $\mathrm{Ti}^{3+}$ を添加 すると比抵抗が減少し, $\mathrm{Ti}^{3+}$ 量の増加とともに約 2 オ一 ダー以上比抵抗が減少した. また活性化エネルギーも小 さくなる傾向にあった.

$\mathrm{Ti}^{3+} 10$ モル $\%$ 以上では，わずかに失透化したガラス となり, 非常に低い比抵抗值を示した.このように $\mathrm{Ti}^{3+}$ の増加と共に比抵抗が減少するのは，バナジウムガラ ス，鉄ガラスと同様に (2) 式のような酸素原子を介して 原子価変化するキャリャー濃度が増加するためと考えら れる。

$$
\mathrm{Ti}^{3+}-\mathrm{O}-\mathrm{Ti}^{4+} \rightleftharpoons \mathrm{Ti}^{4+}-\mathrm{O}-\mathrm{Ti}^{3+}
$$


つぎに一定のチタンイオン濃度を持つガラス（No.14 〜No. 17）において $\mathrm{Ti}^{3+} / \mathrm{Ti}^{3+}+\mathrm{Ti}^{4+}$ と $350^{\circ} \mathrm{C}$ における 比抵抗との関係を図 7 に示した. $\mathrm{Ti}^{3+} / \mathrm{Ti}^{4+}+\mathrm{Ti}^{3+}$ の比 が 0.04 までは比抵抗が急激に減少するが，0.04 から 0.1 まではゆるやかな減少を示した. また失透化で $\mathrm{Ti}^{3+}$ 濃度の高いガラスをえることができなかったため, バナ ジウムガラス，鉄ガラスに見られるよらな比抵抗の極小 值は見出すことはできなかった。

つぎに基礎ガラスに $\mathrm{FeO}, \mathrm{Fe}_{2} \mathrm{O}_{3}, \mathrm{~V}_{2} \mathrm{O}_{3}, \mathrm{~V}_{2} \mathrm{O}_{5}, \mathrm{Nb}_{2} \mathrm{O}_{5}$ をそれぞれ 5 モル\%添加したガラスの比抵抗值を表 2 に 示した. $\mathrm{FeO}, \mathrm{V}_{2} \mathrm{O}_{3}$ を添加したガラスは比抵抗が減少 するが, $\mathrm{Fe}_{2} \mathrm{O}_{3}, \mathrm{~V}_{2} \mathrm{O}_{5}, \mathrm{Nb}_{2} \mathrm{O}_{5}$ を添加したガラスでは比 抵抗がほとんど変化しなかった．また $\mathrm{Ti}^{3+}$ を含むガラ スにおいても $\mathrm{FeO}, \mathrm{V}_{2} \mathrm{O}_{3}$ の添加は比抵抗を減少させ

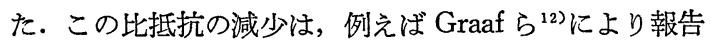
されているような (3) 式で示される電荷移動が生じるた めと考えられるが，さらに詳細な検討が必要である.

$$
\mathrm{Fe}^{2+}+\mathrm{Ti}^{4+} \rightleftharpoons \mathrm{Fe}^{3+}+\mathrm{Ti}^{3+}
$$

\section{5 比抵抗におよぼす結晶化の影響}

No.12 の密封白金チューブ中で結晶化したガラスの比 抵抗の温度依存性を図 8 に示した. 結晶化ガラスにおい ても熱処理前のガラスと同様, 直線の折れ曲りが認めら れた. 熱処理時閒の增加と共に比抵抗および活性化エネ ルギーが減少し，熱処理 4 時間では約 3 オーダの比抵抗 の減少が生じた.この比抵抗の減少は, 析出結晶量にほ ぼ比例していると思われた.一方, 空気中で熱処理した ガラスでは著しい比抵抗の減少が認められなかったが, これはガラス中の $\mathrm{Ti}^{3+}$ が酸化されて, $\mathrm{Ti}^{3+}$ の濃度が低 下したためと考えられた。

結晶化によって比抵抗が著しく減少するのは，マグネ タイト結晶のような, 伝導度の大きい非化学量論的な $\mathrm{Ti}^{3+}$ と $\mathrm{Ti}^{4+}$ を含んだ結晶が析出するためと考えられ る. すなわち $\mathrm{Ti}^{3+}$ および $\mathrm{Ti}^{4+}$ のイオン半径はそれぞ れ $0.69 \AA$ および $0.64 \AA$ (または $0.68 \AA$ ) であるか ら， $\mathrm{Ti}^{3+}$ は $\mathrm{Ti}^{4+}$ に固溶する形で結晶に溶けこむことが できると思われる.この $\mathrm{Ti}^{3+}$ の導電性におよぼす影響 は, $\mathrm{TiO}_{2}$ 単結晶において認められる.すなわち, この $\mathrm{TiO}_{2}$ 単結晶を中性または還元雾囲気で熱処理すると比 抵抗が約 5 10 オーダ減少するが，これは $\mathrm{Ti}^{3+}$ の生成 に起因していると報告 ${ }^{13), 14)}$ されている. また活性化エ ネルギーは，低温側では $0.2 \sim 0.4 \mathrm{eV}$ ，高温側では 0.5 $\sim 0.6 \mathrm{eV}$ となり, 熱処理前のガラスの活性化エネルギ 一に比べて小さくなった.

\section{6 熱起電力}

$\mathrm{Ti}^{3+}$ を含んだガラス (No. 11) のゼーベック係数 $\alpha$ と 温度との関係を図 9 に示した.ゼーベック係数は, 温度依 存性がほとんど認められない。これはキャリヤ一濃度が 温度に対して無関係で一定であることを意味している。

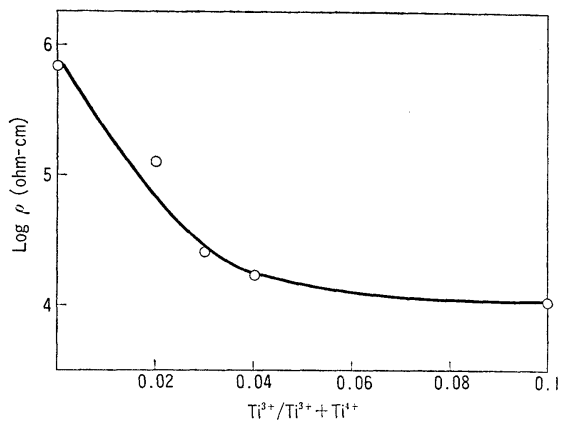

Fig. 7. The relation between $\log \rho 350^{\circ} \mathrm{C}$ and $\mathrm{T}^{3+} /$ $\mathrm{Ti}^{3+}+\mathrm{Ti}^{4+}$ in glasses of No. $14 \sim$ No. 17 .

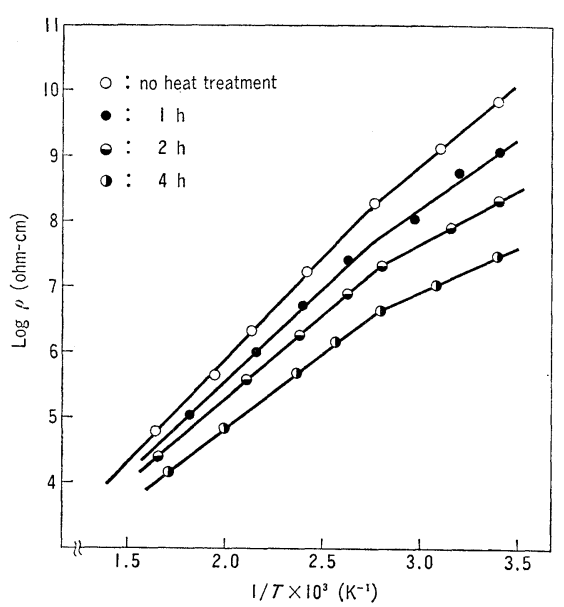

Fig. 8. The temperature dependence of resistivity for the glasses heated at $800^{\circ} \mathrm{C}$ (No 12).

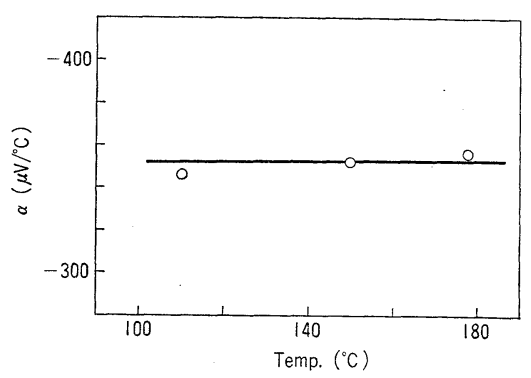

Fig. 9. Seebeck coefficient vs. Temperature for glass containing $3 \mathrm{~mol} \% \mathrm{Ti}^{8+}$ (No 11 ).

Table 2. Resistivity of glasses containing $5 \mathrm{~mol} \%$ additives.

\begin{tabular}{lc}
\hline Additives & $\rho_{20}{ }^{\circ} \mathrm{C}(Q-\mathrm{cn})$ \\
\hline $\mathrm{FeO}$ & $5 \times 10^{10}$ \\
$\mathrm{~V}_{2} \mathrm{O}_{3}$ & $3 \times 10^{10}$ \\
$\mathrm{Fe}_{2} \mathrm{O}_{3}$ & $2 \times 10^{11}$ \\
$\mathrm{~V}_{2} \mathrm{O}_{5}$ & $8 \times 10^{10}$ \\
$\mathrm{Nb}_{2} \mathrm{O}_{5}$ & $6 \times 10^{11}$ \\
$*$ Base glass & $6 \times 10^{11}$ \\
\hline
\end{tabular}

*Base glass : $10 \mathrm{~K}_{2} \mathrm{O}-50 \mathrm{TiO}_{2}-40 \mathrm{P}_{2} \mathrm{O}_{5}$ 
このゼーベック係数は, $-0.36 \mathrm{mV} /{ }^{\circ} \mathrm{C}$ の值であり, この符号が負であることからキャリヤーは電子である.

またこのゼーベック係数は，Heikes ${ }^{15)}$ らによりホッ ピング伝導機構を用いて (4) 式の様に表わされている.

$\alpha=k / e \ln (C / 1-C)$

ここで $は$ はゼーベック係数， $k$ はボルツマン定数， $e$ は 電子の電荷， $c$ はキャリヤー濃度である.さらに Mackenzie ${ }^{16)}$, Allersma ${ }^{17)}$ らは，(4) 式を用いて $\mathrm{V}_{2} \mathrm{O}_{5}$ を含 むガラス半導体についてゼーベック係数を求め, 実験值 とよく一致すると報告している. そこでバナジウムガラ スと同様にチタンガラスについて $\alpha$ を求めると -0.28 $\mathrm{mV} /{ }^{\circ} \mathrm{C}$ となり，実測值よりわずかに小さくなった.こ れはガラス中の $\mathrm{Ti}^{3+}$ の分析誤差に起因するのが主原因 と考えられた.

\section{4. 総括}

$\mathrm{RO}\left(\mathrm{R}_{2} \mathrm{O}\right)-\mathrm{TiO}_{2}-\mathrm{P}_{2} \mathrm{O}_{5}$ 系 $(\mathrm{R}=\mathrm{K}, \mathrm{Ca}, \mathrm{Be})$ のガラス 化範囲を調べ，えられたガラスの電気伝導性を検討した 結果，つぎのことが明らかとなった。

（1） 3 つつの系のガラス化範囲は，よく類似してお り，ガラス中の $\mathrm{TiO}_{2}$ の最大濃度は 65 モル \% であっ た.

(2) $10 \mathrm{~K}_{2} \mathrm{O}-50 \mathrm{TiO}_{2}-40 \mathrm{P}_{2} \mathrm{O}_{5} 3$ 成分系ガラスを $800^{\circ} \mathrm{C}$ で熱処理すると $\mathrm{TiO}_{2}$ (anatase) および末知結晶 $\left(x \mathrm{~K}_{2} \mathrm{O} \cdot y \mathrm{TiO}_{2} \cdot z \mathrm{P}_{2} \mathrm{O}_{5}\right)$ が析出した. $\mathrm{Ti}^{3+}$ を含むガラ スにおいても同様な結晶が認められた.

（3）チタンを含む燐酸塩ガラスの比抗抵の温度依存 性は次式に従い, $100^{\circ} \mathrm{C}$ 付近で $\log \rho$ と $1 / T$ の直線で折 れ曲りを生じた。

$$
\rho=\rho_{0} \exp (\Delta E / k T)
$$

$x \mathrm{RO}\left(\mathrm{R}_{2} \mathrm{O}\right)-(60-x) \quad \mathrm{TiO}_{2}-40 \mathrm{P}_{2} \mathrm{O}_{5}$ 系ガラス $(\mathrm{R}=\mathrm{K}$, Ca) において $\mathrm{TiO}_{2}$ 量の増加

と共に比抵抗が減少した. また $x=10(\mathrm{R}=\mathrm{K})$ のガラス に $\mathrm{Ti}^{3+}$ を 0〜 5 モル\% 添加すると，比抵抗は約 2 オ一 ダ減少し，かつ活性化エネルギーも小さくなった。
（4） $\mathrm{Ti}^{3+}$ と $\mathrm{Ti}^{4+}$ を含む燐酸塩ガラスは, 結晶化す ると非常に比抵抗が減少し, その比抵抗の減少の度合 は，析出結晶量に関係している. すなわち析出結晶量が 多いほど比抵抗が減少した。

結晶化によって比抵抗が著しく減少するのは, $\mathrm{Ti}^{3+}$ と $\mathrm{Ti}^{4+}$ を含んだ伝導度の大きい非化学量論的な結晶が析 出するためと推察された.

（5） $\mathrm{Ti}^{3+}$ を含むガラスのゼーベック係数は，-0.36 $\mathrm{mV} /{ }^{\circ} \mathrm{C}$ であり, この符号が負であることからキャリヤ 一電子であると考えられた。

(6) 含チタンガラスに 5 モル\%の $\mathrm{FeO}$ または $\mathrm{V}_{2} \mathrm{O}_{3}$ を添加すると比抵抗が約 1 オーダ減少した.

\section{文献}

1) E.P. Denton, H. Rawson, J.E. Stanworth, Nature, 173, 1030 (1954).

2) P.I. Baynton, H. Rawson, J.E. Stanworth, J. Electrochem. Soc., 104, 237 (1957).

3）宗像元介, 窯協, 70, 197 (1962).

4）守屋喜郎, 上野 力, 窯協, 71, 169 (1963).

5) J.D. Mackenzie, S.P. Mitoff, “Semiconducting Glass”, U.S. Pat. 3,258, 434 (1966).

6）小野節子, 宗像元介, 窯協, 82, 511 (1974).

7) K.W. Hansen, M.T. Splan, J. Electrochem. Soc. 113, 895 (1965).

8）並河 洋, 熊田 虔, 窯協, 76, [3] 10 (1968).

9）土谷敏雄, 森谷太郎, 窯協, 81, [7] 303 (1973).

10). H.R. Killias, Physics Letters, 20, 5 (1966).

11）宗像元介, 岩本正治郎, 窯協, 68, [5] 57 (1960).

12) M.A.C.G. van de Graaf, K.J. De Vries, A.J. Burggraaf, Physics Chem. Glasses, 14, [3] 53 (1973).

13) E.H. Greener, F.J. Barone, W.M. Hirthe, J. Am. Ceram. Soc., 48, 623 (1965).

14) Ph. Odier, J.F. Baumard, D. Panis, A.M. Anthony, J. Solid State Chem., 12, 324 (1975).

15) R.R. Heikes, R.W. Ure, "Thermo-electricity, Chapter 4," Interscience Publishers, New York, London (1961).

16) T.N. Kennedy, J.D. Mackenzie, Physics and Chemistry of Glasses, [5] 169 (1967).

17) T. Allersma, J.D. Mackenzie, J. Chem. Phys., 47, 1406 (1967). 